\title{
Assessment of Palm Kernel Shells as Partial Replacement of Coarse Aggregates in Highway Pavements
}

\author{
Apeh Ocholi Adejoh Samuel \\ Department of Civil Engineering, The Federal Polytechnic Idah, North Central, Nigeria \\ Email address: \\ engrsamapeh $@$ gmail.com

\section{To cite this article:} \\ Apeh Ocholi Adejoh Samuel. Assessment of Palm Kernel Shells as Partial Replacement of Coarse Aggregates in Highway Pavements. \\ International Journal of Engineering Management. Vol. 4, No. 2, 2020, pp. 25-29. doi: 10.11648/j.ijem.20200402.12
}

Received: February 3, 2020; Accepted: February 18, 2020; Published: August 27, 2020

\begin{abstract}
This paper looked at the potentials of partially replacing palm kernel shells with coarse aggregates in road binder course with emphasis on strength of the asphalt concrete as given by the Marshal Stability and flow values. The aim of the study was to assess the suitability of replacing coarse aggregates with palm kernel shells in highway pavements. The following methodology was adopted in the research, Specified proportions of each material such as $4 \%$ filler of size $0.075 \mathrm{~mm}, 35 \%$ quarry stone dust of maximum size $5 \mathrm{~mm}, 6 \%$ river sand of maximum size $5 \mathrm{~mm}$ also and $20 \%$ crushed stone of size $5-16 \mathrm{~mm}$, 35\% crushed stone of size $16-20 \mathrm{~mm}$ with $6 \%$ bitumen of penetration grade $60 / 70$ was mixed together at $163^{\circ} \mathrm{C}$. The mixture was compacted with 50 blows both at the top and bottom to obtain cylindrical samples for the Marshall Stability tests. Palm kernel shells were partially replaced at $0 \%, 20 \%, 30 \%, 40 \%, 50 \%, 60 \%, 70 \%, 80 \%$, and $100 \%$ by weight of total coarse aggregate in the mixture. The study found that palm kernel shells can be used to replace coarse aggregate up to $20 \%$ before drastic reductions become noticeable. It is therefore recommended that for heavily trafficked roads, palm kernel shells up to $10 \%$ can be used for the replacement while even above $70 \%$ replacement is possible for lightly trafficked roads in the rural settings.
\end{abstract}

Keywords: Palm Kernel Shells, Coarse Aggregate, Fine Aggregate, Bitumen, Filler Material, Asphalt Concrete

\section{Introduction}

Concrete is a man-made material used in the construction industry globally. It has great versatility and it is relatively cheap in filling wide range of needs. These qualities has made it to be a competitive building material [9]. The production of concrete is used in infrastructural development and also creates employment opportunities all over the world. Cement, Sand and Coarse aggregates such as granite, must be available before concrete can be produced, incidentally the costs of these materials have risen astronomically over the past few years. But in spite of the rising cost of production, the demand for concrete is increasing. The increasing demand for concrete has a negative effect on depletion of aggregate deposits; environmental degradation and ecological imbalance. The possibility of complete depletion of aggregates resources in the near future can therefore not be over emphasized, because it is possible. We would be mistaking a big to think that these natural resources will not finish one day. That is why all hands must be on deck to sustain them, and/or make construction projects as sustainable as possible. The need to reduce costs of construction and environmental degradation has necessitated research into the use of alternative materials, especially locally available ones which can replace conventional ones used in concrete production [5].

The world is currently living on wastes time bomb, including agricultural and industrial wastes, which have created waste management and pollution problems. But if we decide to use these agricultural and industrial wastes to complement other traditional materials in construction, we are sure of reaping both practical and economic advantages. The wastes generally have no commercial value, it is acquired almost free of charge and it is locally available, making transportation cost is very low.

Palm Kernel Shell (PKS) is one of the waste materials obtained during the crushing of palm nuts in the palm oil mills for palm oil extraction. These are agricultural waste products and are available in large quantities in the tropical regions of the world. Palm kernel shells are mostly used as a source of fuel for domestic cooking in most areas where they occur. 
Normally, the Palm kernel shell is obtained by breaking the palm nut. Shells are lightweight in nature, but hard and come in different shapes and sizes. Further, the shells are often dumped as waste products of the oil palm industry [12]

The maximum size of PKS is found about $15 \mathrm{~mm}$. Though the sizes of PKS may vary depending upon the type of machinery used to crack the palm nuts, generally the size of the shells are in the range of 2 to $15 \mathrm{~mm}$. The shells are flaky, parabolic, angular, and possess smooth concave and convex surfaces. The thicknesses of PKS vary in the range of 1.5 - 3 $\mathrm{mm}$. Past research works carried out on PKS focused on using the shells of different sizes above $3 \mathrm{~mm}$ after removing smaller particles less than $3 \mathrm{~mm}$.

In Nigeria, about 1.5 million tons of PKS are produced annually; most of which are often dumped as waste products [5]. The waste could be converted to wealth by using it in the production of asphaltic concrete.

\subsection{Background of Study Area}

Idah, town, Kogi state, south-central Nigeria. It lies on a sandstone cliff on the east bank of the Niger River. The traditional capital of the Igala people, Idah was brought under the jurisdiction of the kingdom of Benin by Oba (King) Esigie in the early 16th century. From Benin the polity of Idah adopted both a system of kingship and the art of cire perdue ("lost wax") casting in bronze. Tsoede, the son of an early Ata ("king"), left Idah and conquered and refounded the kingdom of Nupe (near the confluence of the Niger and Kaduna rivers); he is also said to have introduced to the Nupe people the art of bronze casting, for which they later became well known.

During the 19th century Idah was a thriving port, trading palm oil and kernels and rubber to Europeans and staple crops, cotton, woven cloth, horses and other livestock, pots, and knives to the Igbo people just to the south. The Igala were able to maintain strict control over the lower Niger trade north of Idah (no Igbo boats were allowed above the port), partially because just south of the town the Niger valley emerges from a narrow, rocky section to some wide, extensive floodplains.

Modern Idah remains a major trading centre (palm produce, yams, cassava [manioc], rice, fish) on the river. Besides trade and farming, the local population is engaged in making canoes, fishing nets, and soap; handicrafts and cotton weaving are also significant. There are limestone deposits in the vicinity and coal deposits near Ankpa, 68 miles (109 km) east-northeast.

Christianity and Islam are the predominant religions of the town. Christian missionaries have been active among the Igalas since the 1860s, and Idah's Roman Catholic community sponsors both a secondary school and a teachertraining college and several other public and private secondary schools are found in Idah town. The Federal Polytechnic is also located in Idah, a Government Technical school, and a public hospital and many privately owned hospitals and clinics. Roads from the town lead to Nsukka and Anyigba, and there is ferry service to Agenebode across the Niger River. [13].

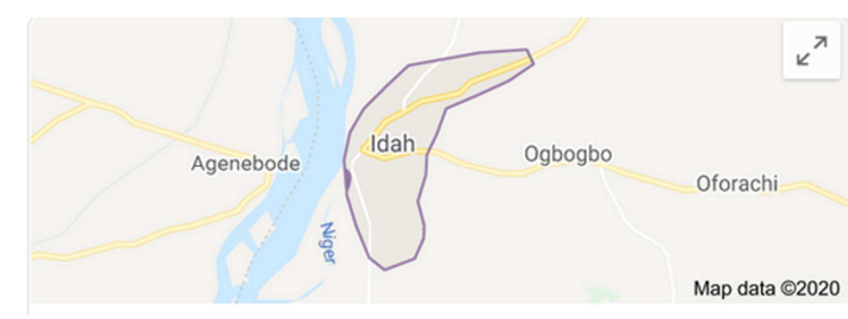

Figure 1. Map of Idah.

\subsection{Problem Statement}

The cost of construction materials has been increasing, while the demand for good quality roads in Nigeria is growing. And naturally occurring materials are becoming scarce with each passing day. This is the reason why the search for alternative and sustainable materials, capable of satisfying the requirements of good quality roads is the focus of study among researchers in the $21^{\text {st }}$ century.

\subsection{Aim}

The aim of this research is to assess the suitability of palm kernel shell (PKS) as a partial replacement for coarse aggregates in asphalt concrete, while the objectives of this research are (i) to investigate the properties of asphaltic concrete when palm kernel shell is used as partial replacement of coarse aggregates, (ii) to study the material (palm kernel shell) characteristics, (iii) to study the characteristics of Asphaltic concrete with palm kernel shell as partial replacement of coarse aggregates, and (iv) to reduce the pressure on naturally availability materials by replacing aggregates with palm kernel shells

\section{Literature Review}

Asphaltic concrete is derived from a mixture of coarse and fine aggregates, stone dust, mineral fillers and binder, usually bitumen. The mix is done to ensure that the finished product does not have too much bitumen that could lead to bleeding and frictionless surface, or too much coarse aggregate leading to removal of the surface. Several researchers have used locally available materials to partially or fully replace these costly conventional materials in both concrete mixture and asphaltic mixture. Apart from the fact that these conventional construction materials are costly, they are also becoming scarce due to population growth, increased urbanisation and rapid infrastructural development to meet up with population growth. [10] Investigated the properties of bitumen modified with used tyre. Basic tests such as penetration, softening point, viscosity, flash and fire point and ductility test were carried out by using shredded waste tyre which varied from $0 \%$ to $20 \%$ by weight of $60 / 70$ penetration grade bitumen at $1600^{\circ} \mathrm{C}$ using dry mix method. Penetration value decreased with addition of $20 \%$ tyre while increase in softening point, viscosity, flash and fire point were obtained with the corresponding values of $80.9^{\circ} \mathrm{C}$, 
$250.96 \mathrm{sec}$ and $189 / 280.120 \mathrm{C}$ respectively.

[11] Examined the performance of palm kernel shells as coarse aggregates in road binder courses focusing on strength of the asphalt concrete as given by the Marshal Stability and flow values. It was observed that palm kernel shells can be used to replace coarse aggregate up to $30 \%$ before drastic reductions become noticeable. He recommended that for heavily trafficked roads, palm kernel shells up to $10 \%$ can be used for the replacement while even $100 \%$ replacement is possible for lightly trafficked roads in the rural settings.

Palm kernel shells (PKS) are hard, carbonaceous, and organic by- products, PKS consists of small size particles, medium size particles and large size particles in the range 0 $5 \mathrm{~mm}, 5-10 \mathrm{~mm}$ and $10-15 \mathrm{~mm}[1,12]$. The shells have no commercial value, but create disposal and waste management concerns. [8] Investigated the suitability of sawdust and palm kernel shells as replacement for fine and coarse aggregate in the production of reinforced concrete slabs. He concluded that $25 \%$ sawdust and palm kernel substitution reduced the cost of concrete production by $7.45 \%$. He also said that it is possible to partially replace sand and granite with sawdust and palm kernel shell in the production of lightweight concrete slabs.

\section{Materials and Method}

\subsection{Materials}

Palm kernel shell used for this research had a maximum size of $15 \mathrm{~mm}$ and a minimum size of $3 \mathrm{~mm}$, the thicknesses of PKS used vary from $1.5 \mathrm{~mm}-4 \mathrm{~mm}$. The medium size particles ranging from $5-10 \mathrm{~mm}$ (consisting of $70 \%$ of the total PKS) was used in this study. The PKS was obtained locally from Mr. Apeh Ocholi's farm at Odu Ofugo in Dekina Local Government Area of Kogi State, Nigeria, the shells were flushed with hot water to remove dust and other impurities that could be detrimental to concrete. They were sun-dried and oven dried at a temperature of $400^{\circ} \mathrm{C}$, crushed and sieved with sieve No 200. Packed in plastic sheets to prevent contact with water. Filler and coarse aggregate were obtained from Avookee quarry site at Lokoja, Kogi State, Nigeria. Natural river sand free from deleterious materials was obtained from a riverine area in Idah town, Kogi state.

Ordinary Portland cement manufactured by Dangote Cement Factory at Obajana in Kogi State, Nigeria, conforming to BS 12 (1996) was used in the concrete production. Water used in mixing the materials was from the Federal Polytechnic Idah borehole. The water looked clean and was free from any visible impurities. It conformed to the requirements of BS 1348 (1980) [4].

Bitumen with penetration grade of 60/70 was obtained from Kaduna Petrochemical Refinery, Kaduna State, Nigeria.

The study was carried out in the concrete laboratory of the Federal Polytechnic Idah utilized one control mix ratio of $1: 2: 4$, batched by weight. A water cement ratio of 0.6 was used for the mix. The percentage replacements of the aggregates by Palm Kernel Shells (PKS) were $0 \%, 20 \%, 50 \%$,
$60 \%, 70 \%, 80 \%$ and $100 \%$ by weight. The casting was done in cast iron moulds measuring $150 \mathrm{~mm} \times 150 \mathrm{~mm} \times 150 \mathrm{~mm}$ internally. The specimens were made in accordance with BS 1881 (1996) [2].

\subsection{Method}

Specified proportions of each material such as $4 \%$ filler of size $0.075 \mathrm{~mm}, 35 \%$ quarry stone dust of maximum size $5 \mathrm{~mm}$, $6 \%$ river sand of maximum size $5 \mathrm{~mm}$ also and $20 \%$ crushed stone of size $5-16 \mathrm{~mm}, 35 \%$ crushed stone of size $16-20 \mathrm{~mm}$ with $6 \%$ bitumen of penetration grade $60 / 70$ was mixed together at $163^{\circ} \mathrm{C}$. The mixture was compacted with 50 blows both at the top and bottom to obtain cylindrical samples for the Marshall Stability tests. Palm kernel shells were partially replaced at $0 \%, 20 \%, 30 \%, 40 \%, 50 \%, 60 \%, 70 \%, 80 \%$, and $100 \%$ by weight of total coarse aggregate in the mixture.

\section{Physical properties of the palm kernel shells}

Table 1 gives the physical properties of the palm kernel shells while the particle size distribution is shown in figure 1 .

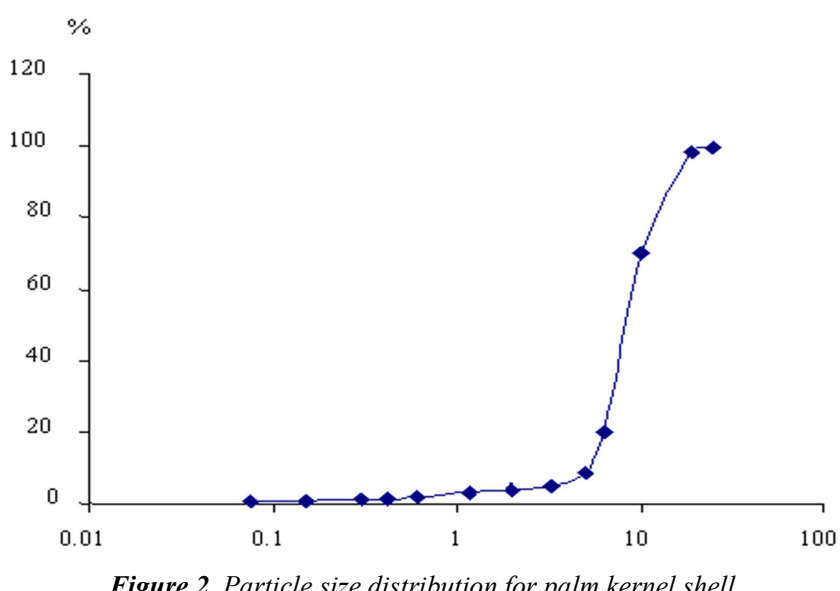

Table 1. Physical properties of the Palm kernel shells.

\begin{tabular}{ll}
\hline Property & Value \\
\hline Bulk density $\mathrm{Mg} / \mathrm{m}^{3}$ & 0.72 \\
Dry density $\mathrm{Mg} / \mathrm{m}^{3}$ & 0.66 \\
Void ratio & 0.41 \\
Porosity (\%) & 29 \\
Water content (\%) & 9 \\
Water absorption (\%) & 13 \\
Specific gravity & 1.63 \\
Impact Value (\%) & 4.48 \\
\hline
\end{tabular}

The specific gravity of the palm kernel shells does not place it in the category of common rock groups whose gravities range from 2.62-3.00. However, it showed same porosity as granite, quartzite, far above limestone. The arrangement of the shells as they touched each other would have accounted for this. Dry density values place the palm kernel shells in the same category as lightweight aggregate especially pumice, scoria or vermiculate for natural and fly ash and clinker for processed aggregates $[6,14]$.

Properties of Binder

The binder used in the production of binder courses for roadway pavements is the petroleum bitumen of grade 60-70, 
whose properties were obtained in the laboratory thus, and shown in Table 2.

Table 2. Properties of the Petroleum Bitumen 60-70.

\begin{tabular}{ll}
\hline Property & Test Values \\
\hline Specific gravity at $25^{\circ} \mathrm{C}$ & 1.06 \\
Softening Point $\mathrm{R}$ and $\mathrm{B}\left({ }^{\circ} \mathrm{C}\right)$ & 51 \\
Penetration at $25^{\circ} \mathrm{C}-0.1 \mathrm{~mm}$ & $60-70$ \\
Ductility at $25^{\circ} \mathrm{C}(\mathrm{cm} / \mathrm{min})$ & 100 \\
Loss on heating after 5 hours at $163^{\circ} \mathrm{C}$ in $\%$ by weight of & 0.2 \\
mix & 99.2 \\
Solubility in Trichloroethane $\%$ by weight & 20.6 \\
Drop in penetration after heating $(\%)$ & 250 \\
Flash point (open cup) ${ }^{\circ} \mathrm{C}$ min & 0.6 \\
Ash \% by weight & \\
\hline
\end{tabular}

All the tests conform to BS 598 for bitumen to be used in binder courses (BS 598, 1985) [3].

Properties of the mix

Figure 2 shows a distribution of all the components of the mix as specified. These were carried out as specified in BS
812.

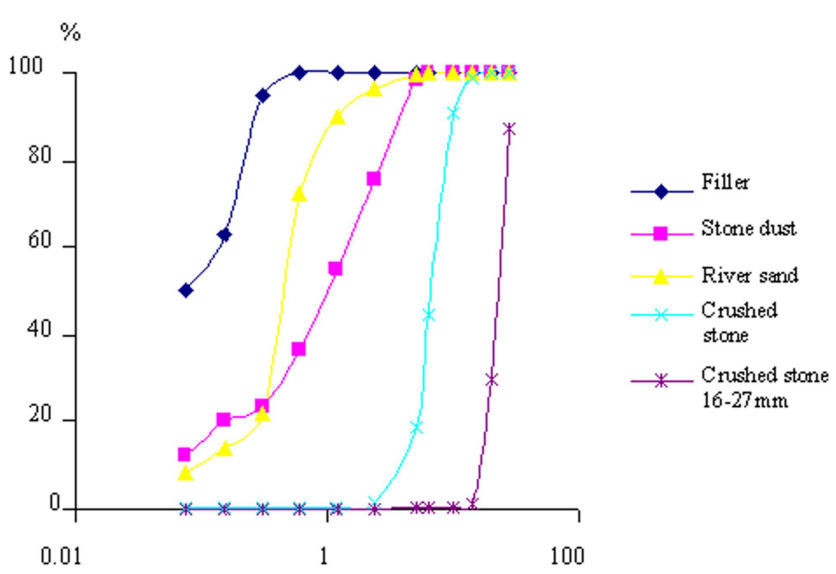

Figure 3. Particle size distribution for the constituent materials for asphalt concrete.

Values for the Marshal Stability and flow are shown in Table 3.

Table 3. Strength Characteristics of the Asphalt Concrete.

\begin{tabular}{|c|c|c|c|c|c|}
\hline Palm kernel ratio (\%) & Impact value (\%) & Density $\left(\mathrm{kg} / \mathrm{m}^{3}\right)$ & Water absorption (\%) & Marshal Stability (kN) & Flow (mm) \\
\hline 0 & 20.61 & 2.38 & 0.2 & 14.48 & 3.38 \\
\hline 10 & 16.59 & 2.27 & 1.3 & 13.36 & 3.72 \\
\hline 30 & 12.40 & 1.85 & 6.5 & 11.76 & 3.82 \\
\hline 50 & 11.23 & 1.76 & 8.6 & 11.09 & 3.88 \\
\hline 70 & 10.64 & 1.74 & 8.4 & 10.80 & 4.00 \\
\hline 100 & 4.51 & 1.71 & 14.7 & 7.62 & 4.22 \\
\hline
\end{tabular}

\section{Discussions}

From the particle size distribution in Figure 1, the palm kernel shells will act as stone dust, sand and coarse aggregate even as mineral fillers by virtue of the distribution. Proportions of materials retained on $5.00 \mathrm{~mm}$ sieve were weighed and used for the mixes. This was done to avoid altering the properties of the other components of the mix. The effect here is that palm kernel shells will replace mostly the coarse aggregate between range 5 and $16 \mathrm{~mm}$.

It was observed that on the average as the coarse aggregates were reduced and palm kernel Shells added, the Marshall stability reduced while the flow increased. This is to be expected because a reduction in flow implies more strength for the mix. Marshall Stability value of $14.48 \mathrm{kN}$ was obtained using granite alone as coarse aggregate and $7.62 \mathrm{kN}$ using palm kernel shells alone as coarse aggregates. This shows a reduction in percentage of up to $47 \%$.

Marshall Stability range for road surfaces carrying between 1 and 6000 commercial vehicles per day should be between 2 and $10 \mathrm{kN}$ [7]. This means that with the proper stress calculation and appropriate thicknesses of underlying layers, even the asphalt concrete with $100 \%$ palm kernel shells is suitable for lightly trafficked roads. Since the same amount of bitumen was used, the flow values are almost similar. The increase would have been caused by the weaker bonds created by the palm kernel shells and their high water retention capacity capable of making the bitumen to increase its water content, and by extension viscosity.

The results showed that flow values increased, but they still fell below the specified range of $5 \mathrm{~mm}$ maximum.

\section{Conclusions}

Judging by the results obtained from the tests, it can be concluded that:

1) Palm kernel shells can be used as partial replacement for coarse aggregate up to $10 \%$ for heavily trafficked roads and $50 \%$ for light trafficked roads.

2) Palm kernel shells can be used as full replacement for the coarse aggregates for lightly trafficked roads, mostly in the rural areas. This will go a long way into reducing construction and maintenance costs of these roads. This will also reduce the depletion of scarce coarse aggregate, thereby conserving it for future generations.

3) The quest by government to sustain the environment by encouraging the use of locally available materials in infrastructure development will be met with the use of palm kernel shells as a road construction material.

4) This will encourage the rural dwellers to plant more palm trees, from which the shells could be gotten, to boost their economic power. 


\section{References}

[1] Alengaram U. J, Jumaat M. Z, Mahmud H. (2010). Ductility Behaviour of Reinforced Palm Kernel Shell Concrete Beams. Eur. J. Scientific Res., 23: 406-420.

[2] BS 1881, Testing of Concrete, 1996.

[3] British Standards Institution (BS 598, 1985). Methods of determination of index properties of pitch-bitumen Binder, pp. 2-16, 1985.

[4] British Standard Institution. (1980). BS 3148 Part 2 Test of Water for Making Concrete. London: BSI.

[5] British Standards Institution (BS 812, 1975), Methods of determination of mechanical properties of aggregate, 1995, Part 3, p. 4-8.

[6] Mefteh O, Kebaili H, Oucief L, Berredjem N. A. (2013). Influence of moisture conditioning of recycled aggregates on the properties of fresh and hardened concrete. J Clean Prod 54: 282-288.

[7] Nuhu-Koko M. K. (1990). The use of Palm kernel shells as aggregates for concrete, Paper presented at 21st Annual Conference of Materials Testing, Control and Research, Federal Ministry of Works, Lagos, Nigeria.

[8] Noh Irwan Ahmad, Khairulzan Yahya, (2014). "The effect of oil palm shell as coarse aggregate replacement on densities and compressive strength of concrete", Faculty of civil engineering, Universiti teknologi malaysia, oil palm ind. Econ. J. 1 (3): 32-36.

[9] Oglesby, C, and Hicks, R. (1982). Highway Engineering, fourth edition, John Wesley and sons, New York.

[10] Olutoge, F. A. (2010). Investigations on sawdust and palm kernel shells as aggregate replacement. APRN Journal of Engineering and Applied Science, 5 (4), 7-13.

[11] Pelisser F, Zavarise N, Longo T. A, Bernardin A. M. (2011) Concrete made with recycled tire rubber: effect of alkaline activation and silica fume addition. J Clean Prod 19 (6): $757-$ 763.

[12] Sashidar, C. and Rao, H. S. (2010). Durability Studies on Concrete with Wood Ash Additive. 35th Conference on Our World in Concrete and Structures, August 2010, Singapore.

[13] Ukwedeh, J. N. (2017). "History of Igala Kingdom". 4th ed. Arewa House Press, Ahmadu Bello University.

[14] Zarina Itam, Salmia Beddu, Nur Liyana Mohd Kamal, Md Ashraful Alam, Usama Issa Ayas, (2016). "The feasibility of palm kernel shell as a replacement for coarse aggregate in lightweight concrete", International conference on advances in renewable energy and technologies (ICARET) IOP publishing, doi: 10.1088/17551315/32/1/012040. 